236

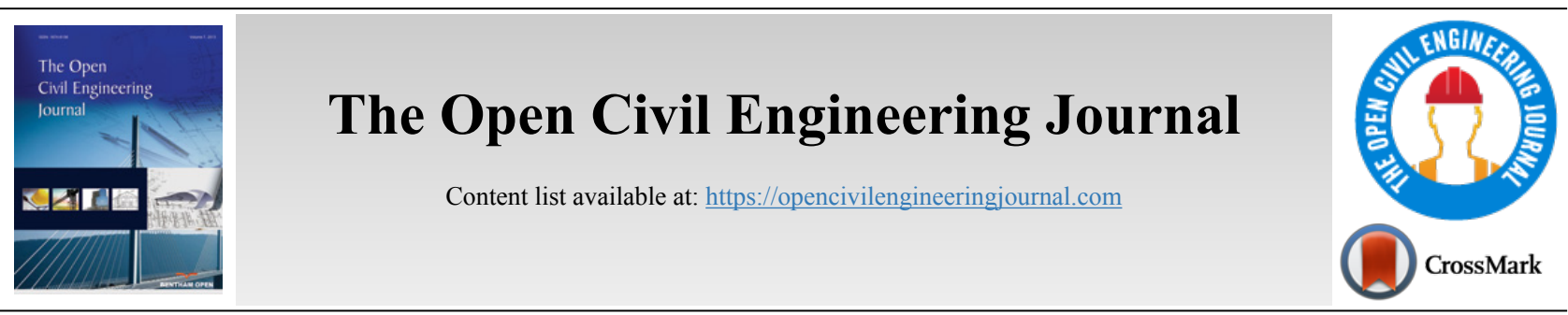

RESEARCH ARTICLE

\title{
Producing Sustainable Concrete using Nano Recycled Glass
}

\author{
Zena K. Abbas ${ }^{1}$, Hayder A. Mahdi ${ }^{1}$ and Bassam A. Tayeh ${ }^{2, *}$ \\ ${ }^{1}$ Civil Engineering Department, University of Baghdad, Baghdad, Iraq \\ ${ }^{2}$ Civil Engineering Department, Faculty of Engineering, Islamic University of Gaza, Gaza, Palestine
}

\begin{abstract}
:
Background:

Many tools and techniques have been recently adopted to develop construction materials that are less harmful and friendlier to the environment. New products can be achieved through the recycling of waste material. Thus, this study aims to use recycled glass bottles as sustainable materials.

Objective:

Our challenge is to use nano glass powder by the addition or replacement of the weight of the cement for producing concrete with enhanced strength.

Methods:

A nano recycled glass powder is prepared by crushing and storming a glass bottle to obtain a Blaine surface area of approximately $28 \mathrm{~m}^{2} / \mathrm{g}$ and conforming to the chemical requirements for natural pozzolana class N, according to ASTM C618. The outcome of using nano recycled glass for theaddition and replacement of ordinary Portland cement weight on the compressive and flexural strengths of concrete at 7,28 , and 90 days is investigated.

Results:

The concrete mixes with $2.5 \%, 5 \%, 7.5 \%$, and $10 \%$ replacements of cement by nano recycled glass powder show improvements in compressive and flexural strengths of up to $12.77 \%$ and $7.66 \%$, respectively, at 28 days. Meanwhile, mixes with the addition of $5 \%$ nano glass powder show best improvements in compressive and flexural strengths of up to $11.49 \%$ and $7.46 \%$, respectively.
\end{abstract}

Keywords: Recycled materials, Nano glass powder, Addition and replacement of cement, Emission of $\mathrm{CO}_{2}$, Flexural strengths of concrete, Raw material.

\begin{tabular}{|l|l|l|l|}
\hline Article History & Received: February 19, 2021 & Revised: April 16, 2021 & Accepted: May 11, 2021
\end{tabular}

\section{INTRODUCTION}

The emission of carbon dioxide and the reduction in raw materials is important in the production of cement. Thus, the use of recycled material as a replacement for cement can be a good solution to eliminate pollution and a good way to dispose wastes [1 - 4]. Shruthi et al. found that the addition of $15 \%$ glass powder with a size less than $90 \mu \mathrm{m}$, which acts as a filler and pozzolanic material, enhances strength [3]. Islam et al. studied the $0 \%-25 \%$ replacements of cement while the cement + glass ratio is kept constant for all replacement levels. The optimum glass content is $20 \%$ for concrete mix with a slight increase in compressive strength of up to $2 \%$ at 90 days com-

\footnotetext{
Address correspondence to this author at Department of Civil Engineering, Faculty of Engineering, Islamic University of Gaza, Gaza, Palestine;

Tel: 00972595174717; E-mail: btayeh@iugaza.edu.ps
}

pared with the control concrete specimen [4]. Mohammad et al. investigated the replacements of cement by glass powder with $5 \%, 10 \%, 15 \%, 20 \%, 25 \%$, and $30 \%$ in the concrete mix. They found that $20 \%$ replacement of cement by glass powder shows higher compressive and flexural strengths of up to $18 \%$ and $27 \%$, respectively, compared with the reference mix at 28 days. They also found that waste glass powder of less than $75 \mu \mathrm{m}$ exhibits higher strength than the counterpart of $90-150 \mu \mathrm{m}$ [5]. Al-Zubaidi et al. used different waste glasses (neon, brown, and green glasses) as a replacement of cement weight with $11 \%, 13 \%$, and $15 \%$ for each type of glass. They found that the compressive and flexural strengths have maximum results at $13 \%$ replacement of weight of cement by neon glass [6]. The addition or replacement of nano-silica by the weight of cement is a new technology in concrete construction [7 - 9]. 
The results of nanomaterial addition to concrete show improvements in mechanical and transport properties, especially for the blend of silica nanoparticles and silica fume $[10,11]$. The mechanism of the reaction between the Portland cement and nano-silica is the same as a pozzolanic reaction but with a higher rate. The high fineness with high silica content accelerates hydration between calcium hydroxides; the reason is that silicate hydration of cement with nano-silica forms an additional cementitious gel, which results in the densification of microstructure in cement mortar and concrete [12 - 17]. The use of a combination of colloidal silica and superplasticizer has the same effectiveness as the use of nano-silica $(7 \%$ as substitution of additives) in enhancing compressive strength in self-consolidation concrete [18]; the high amount of $\mathrm{C}-\mathrm{S}-\mathrm{H}$ formation in normal and self-consolidation concretes introduces more mechanical and durability requirements [18]. The substitution of around 5\% glass powder (specific surface area of $800 \mathrm{~m}^{2} / \mathrm{kg}$ ) for cement leads to the best results of compressive strength [12]. The current study focuses on the combination of using recycled glass waste as sustainable material (natural pozzolana) [19 - 22] after converting it to nano size distribution for activating its effect on the strength properties with minimum cost.

\section{MATERIALS AND METHODS}

\subsection{Materials}

The Ordinary Portland Cement (OPC-Type I) known as (Al Mass) was used in this study. The properties of the cement are presented in Table 1. The properties of the fine aggregate (river sand) with fineness modulus $=2.9$ and the crushed coarse aggregate (gravel) of $19 \mathrm{~mm}$ nominal maximum size are presented in Tables $\mathbf{2}$ and $\mathbf{3}$, respectively. The tests were conducted in the Construction Material Lab in the Civil Engineering Department of the University of Baghdad. The raw material of the west glass bottle was transformed to nanopowder by the process presented in Fig. (1). The properties are presented in Table 4.

Table 1. Properties of cement [23, 24].

\begin{tabular}{|c|c|c|c|c|}
\hline \multicolumn{2}{|c|}{ Tests } & \multirow{3}{*}{$\begin{array}{c}\text { Results } \\
61.5 \\
\end{array}$} & \multicolumn{2}{|c|}{ Limits } \\
\hline & & & ASTM.C150 [23] & IQS. NO.5 [24] \\
\hline \multirow[t]{8}{*}{ Chemical Analysis } & $\mathrm{CaO}, \%$ & & - & - \\
\hline & $\mathrm{SiO}_{2}, \%$ & 20.5 & - & - \\
\hline & $\mathrm{A}_{2} \mathrm{O}_{3}, \%$ & 4.40 & - & - \\
\hline & $\mathrm{Fe}_{2} \mathrm{O}_{3}, \%$ & 4.20 & - & - \\
\hline & $\mathrm{SO}_{3}, \%$ & 2.22 & Max. 2.8 if $\mathrm{C}_{3} \mathrm{~A} \geq 8 \%$ & Max. 2.8 if $\mathrm{C}_{3} \mathrm{~A} \geq 5 \%$ \\
\hline & $\mathrm{MgO}, \%$ & 2.60 & Max. 6.0 & Max. 5.0 \\
\hline & L.O.I., \% & 2.80 & Max. 3.0 & Max. 4.0 \\
\hline & I.R., $\%$ & 0.50 & Max. 0.75 & Max. 1.5 \\
\hline \multicolumn{2}{|c|}{ Blaine Surface Area $\left(\mathrm{m}^{2} / \mathrm{kg}\right)$} & 340 & Min. 280 & Min. 230 \\
\hline \multicolumn{2}{|c|}{ Soundness (Autoclave) \% } & 0.3 & Max. 0.8 & Max. 0.8 \\
\hline $\begin{array}{l}\text { Vicat's } \\
\text { Setting }\end{array}$ & $\begin{array}{c}\text { Initial set (min) } \\
\text { Final set (min) }\end{array}$ & $\begin{array}{c}75 \\
425\end{array}$ & $\begin{array}{c}\text { Min. } 45 \\
\text { Max. } 375\end{array}$ & $\begin{array}{c}\text { Min. } 45 \\
\text { Max. } 600\end{array}$ \\
\hline Compressive Strength (MPa) & $\begin{array}{l}3 \text { days } \\
7 \text { days }\end{array}$ & $\begin{array}{l}17.2 \\
25.6\end{array}$ & $\begin{array}{l}\text { Min. } 12 \\
\text { Min. } 19\end{array}$ & $\begin{array}{l}\text { Min. } 15 \\
\text { Min. } 23\end{array}$ \\
\hline
\end{tabular}

Table 2. Properties of fine aggregate $[25,26]$.

\begin{tabular}{|c|c|c|c|c|}
\hline \multicolumn{2}{|c|}{ Tests } & Passing (\%) & IQS NO.45 (Zone 2) [25] & ASTM Specification C33 [26] \\
\hline \multirow{3}{*}{ Sieve Size (mm) } & 10.0 & 100 & 100 & 100 \\
\cline { 2 - 5 } & 4.75 & 96 & $90-100$ & $95-100$ \\
\cline { 2 - 5 } & 2.36 & 80 & $75-100$ & $50-100$ \\
\cline { 2 - 5 } & 1.18 & 62 & $55-90$ & $50-85$ \\
\cline { 2 - 5 } & 0.60 & 42 & $35-59$ & $25-60$ \\
\cline { 2 - 5 } & 0.30 & 21 & $8-30$ & $5-30$ \\
\hline & 0.15 & 2 & $0-10$ & $0-10$ \\
\hline \multicolumn{2}{|c|}{ Material finer than 75 $\mu \mathrm{m}$} & 2.5 & Max. 5 & - \\
\hline \multicolumn{2}{|c|}{ Sulfate-SO $\mathrm{SO}_{3}(\%)$} & 0.22 & Max. 0.5 & - \\
\hline \multicolumn{2}{|c|}{ Absorption (\%) } & 1.02 & - & - \\
\hline
\end{tabular}


Table 3. Properties of coarse aggregate $[25,26]$.

\begin{tabular}{|c|c|c|c|c|}
\hline \multicolumn{2}{|c|}{ Tests } & Passing (\%) & $\begin{array}{c}\text { IQS NO.45 } \\
\mathbf{( 2 0 - 5 ) ~ m m ~ [ 2 5 ] ~}\end{array}$ & ASTM Specification C33 [26] \\
\hline \multirow{2}{*}{ Sieve Size (mm) } & 37.5 & 100 & 100 & 100 \\
\cline { 2 - 5 } & 19 & 96 & $95-100$ & $90-100$ \\
\cline { 2 - 5 } & 9.5 & 38 & $30-60$ & $20-55$ \\
\cline { 2 - 5 } & 5 & 4 & $0-10$ & $0-10$ \\
\hline Material finer than 75 $\mu \mathrm{m}(\%)$ & 1.05 & Max. 3 & - \\
\hline Sulfate-SO & $(\%)$ & 0.03 & Max. 0.1 & - \\
\hline Absorption (\%) & 0.85 & - & Max. \\
\hline
\end{tabular}

Table 4. Properties of glass powder [27, 28].

\begin{tabular}{|c|c|c|c|}
\hline \multicolumn{2}{|c|}{ Tests } & Nano glass powder & ASTM C618 N[27] \\
\hline \multirow{7}{*}{$\begin{array}{c}\text { Chemical Analysis } \\
\%\end{array}$} & $\mathrm{SiO}_{2}$ & 72.8 & \multirow[t]{3}{*}{ Min. $70 \%$ of $\left(\mathrm{SiO}_{2}+\mathrm{Al}_{2} \mathrm{O}_{3}+\mathrm{Fe}_{2} \mathrm{O}_{3}\right)$} \\
\hline & $\mathrm{A}_{2} \mathrm{O}_{3}$ & 4.5 & \\
\hline & $\mathrm{Fe}_{2} \mathrm{O}_{3}$ & 1.22 & \\
\hline & $\mathrm{CaO}$ & 10 & - \\
\hline & $\mathrm{MgO}$ & 4.37 & - \\
\hline & $\mathrm{SO}_{3}$ & 0.34 & Max. 4\% \\
\hline & L.O.I. & 3.8 & Max. $10 \%$ \\
\hline \multicolumn{2}{|c|}{ Strength activity index (\%)ASTM C311 [28] } & 85 & Min. $75 \%$ \\
\hline \multicolumn{2}{|c|}{ Specific gravity } & 2.23 & - \\
\hline \multicolumn{3}{|c|}{ ineness: amount retained when wet sieving at $45 \mu \mathrm{m}(\%)$} & Max. 34 \\
\hline
\end{tabular}



Fig. (1). Preparation of recycled glass powder.

\subsection{Concrete Mixes and Tests}

The reference concrete mix was designed to provide a compressive strength of $35 \mathrm{MPa}$ for samples in the cylinder at 28 days, according to the ACI 211.1 [29]. The mixed content was in a ratio of (380:685:1010:205) $\mathrm{kg} / \mathrm{m}^{3}$ of cement, river sand, crushed gravel, and water for reference concrete mix (Mrf.). Eight other mixes were prepared by the replacement (4 mixes) and addition (4 mixes) of cement by nano glass powder with $2.5 \%, 5 \%, 7.5 \%$, and $10 \%$. Table 5 presents the mix proportion with slump test results according to ASTM C143 [30]. The mixing process of the concrete mix was achieved according to ASTM C192 [31]. The compressive strength test was made according to ASTM C39/C39 M [32] using (150 × 300) $\mathrm{mm}$ cylinder. The flexural strength test was performed according to ASTM C78 [33] and the prisms of $100 \mathrm{~mm} \times 100$ $\mathrm{mm} \times 300 \mathrm{~mm}$ were used.

\section{RESULTS AND DISCUSSION}

\subsection{Compressive Strength}

The compressive strength lab results are presented in Table 6. Fig. (2) shows the effect of nano glass powder replacement of cement at 7, 28, and 90 days. A slight enhancement is observed at 7 days. This result may be attributed to the nature of glass powder reaction, which is slower than those of other pozzolana types [34 - 36]. Better results are observed at 28 and 90 days. The cumulative percentage increase is shown in Fig. (3) As observed, the compressive strength increases with the rise in the percentage replacement of cements for all ages. The $7.5 \%$ replacement shows best compressive strengths of up to 
$4.68 \%, 12.5 \%$, and $10.12 \%$ at 7,28 , and 90 days, respectively. The results show that it is a good way for the liquidation of west material and recycling in concrete construction. The replacement of nano glass powder is more significant than the addition. The reason is that the former gives better results and is a good way to reduce the consumption of cement, which decreases the effect of its manufacture on pollution. Fig. (4) presents the additions of nano glass powder with $2.5 \%, 5 \%$, $7.5 \%$, and $10 \%$. The compressive strength results show an improvement with more water demand solved by increasing water range; this reduces admixture to maintain slump requirements of design that is due to high fineness and particle behavior [37 - 39]. The 5\% addition of nano glass powder shows optimum improvements in compressive strength of up to $5.4 \%, 10.86 \%$, and $10.37 \%$ at 7,28 , and 90 days, respectively, as presented in the cumulative percentage increase in Fig. (3). The improvement in compressive strength of replacement and addition of recycled nano glass powder is attributed to high fineness. Thus, better filling between cement paste and aggregate and better pozzolanic silica reaction $\left(\mathrm{SiO}_{2}=72.8 \%\right.$ from glass powder and $\mathrm{Ca}(\mathrm{OH})_{2}$ from hydrated cement) are necessary to produce extra gel filling pores with better microstructure of concrete [12 - 17].

\subsection{Flexural Strength}

The flexural strength results are compatible with the compressive strength results, as presented in Table 6. Fig. (5 and 6) show the improvement in the results for replacement and addition, respectively. Cumulative increases for replacement and addition of nano glass powder are presented in Fig. (7) The figure shows that the best replacement results are obtained for $7.5 \%$ replacement and $5 \%$ addition of mixes. Therefore, the replacements are a good way to improve concrete quality with less cement content [40]. The acceptable strength activity index equal to $85 \%$, according to ASTM 618 [27], with high fineness is the main contributor to the improvement in strength in the concrete mix with workability adjusted by superplasticizer [2]. Compressive and flexural strengths presented in Fig. (8) have a good correlation with a high $R^{2}$ of 0.988 .

Table 5. Concrete mix proportion.

\begin{tabular}{|c|c|c|c|c|}
\hline Mix ID & Cement $\mathbf{( k g / \mathbf { m } ^ { 3 } )}$ & Glass powder $\mathbf{( k g / \mathbf { m } ^ { 3 } )}$ & SP L/100 $\mathbf{~ g}$ of cement & Slump (mm) \\
\hline Mrf. & 380 & - & 0.5 & 86 \\
\hline MR 2.5 & 370.5 & 9.5 & 0.5 & 84 \\
\hline MR 5.0 & 361 & 19 & 0.6 & 88 \\
\hline MR 7.5 & 351.5 & 28.5 & 0.65 & 87 \\
\hline MR 10 & 342 & 38 & 0.7 & 90 \\
\hline MA2.5 & 380 & 9.5 & 0.55 & 85 \\
\hline MA5.0 & 380 & 19 & 0.7 & 87 \\
\hline MA7.5 & 380 & 28.5 & 0.85 & 86 \\
\hline MA10 & 380 & 38 & 0.9 & 88 \\
\hline
\end{tabular}

Table 6. Concrete test results.

\begin{tabular}{|c|c|c|c|c|c|c|}
\hline \multirow[t]{2}{*}{ Mix ID } & \multicolumn{3}{|c|}{ Compressive Strength $\left(\mathrm{N} / \mathrm{mm}^{2}\right)$} & \multicolumn{3}{|c|}{ Flexural Strength $\left(\mathrm{N} / \mathrm{mm}^{2}\right)$} \\
\hline & 7 days & 28 days & 90 days & 7 days & 28 days & 90 days \\
\hline Mrf. & 27.8 & 36.8 & 40.5 & 3.68 & 4.96 & 5.65 \\
\hline MR 2.5 & 28.1 & 39.5 & 43.25 & 3.72 & 5.11 & 5.74 \\
\hline MR 5.0 & 28.6 & 41.5 & 44.0 & 3.77 & 5.21 & 5.81 \\
\hline MR 7.5 & 29.1 & 40.8 & 44.6 & 3.82 & 5.34 & 5.91 \\
\hline MR 10 & 28.0 & 39.2 & 42.9 & 3.73 & 5.13 & 5.81 \\
\hline MA 2.5 & 28.1 & 39.2 & 43.0 & 3.70 & 5.15 & 5.76 \\
\hline MA 5.0 & 29.3 & 40.8 & 44.7 & 3.80 & 5.33 & 5.84 \\
\hline MA 7.5 & 28.5 & 40.0 & 43.8 & 3.73 & 5.27 & 5.80 \\
\hline MA 10 & 28.1 & 39.5 & 43.25 & 3.69 & 5.14 & 5.68 \\
\hline
\end{tabular}




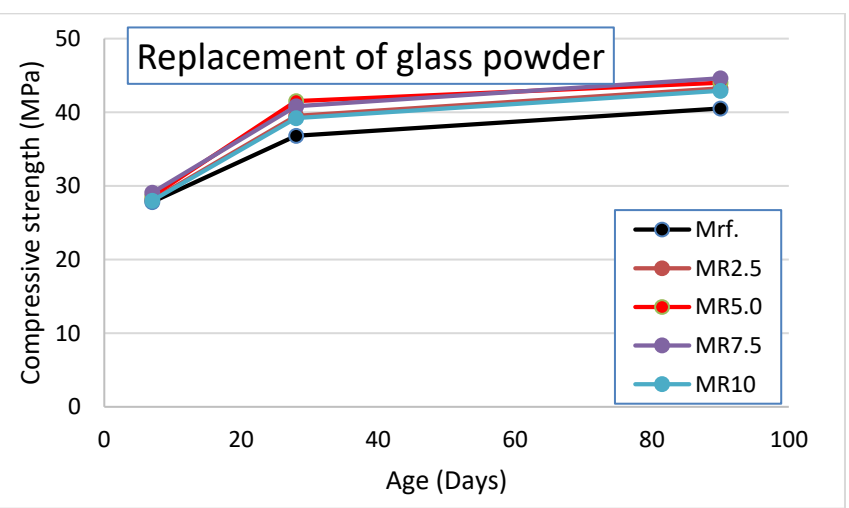

Fig. (2). Development of compressive strength with different weight percentage replacements of glass powder from cement.

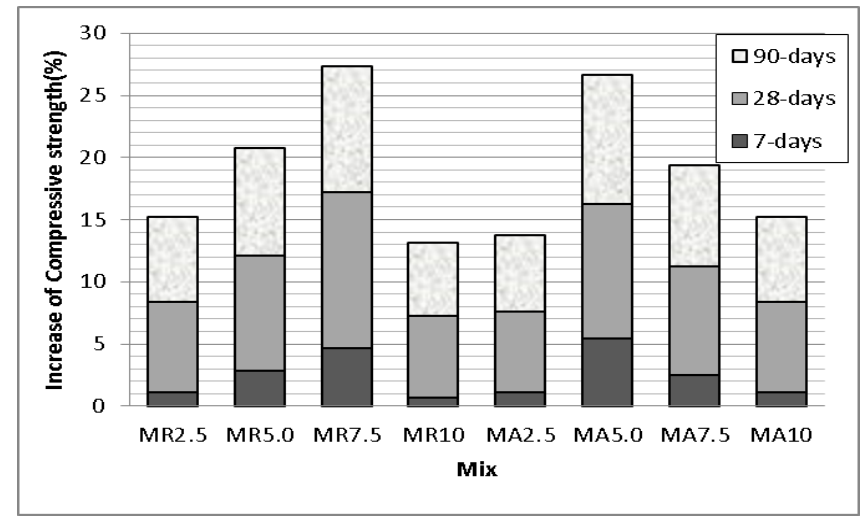

Fig. (3). Cumulative improvement in compressive strength by the replacement and addition of glass powder.



Fig. (4). Development of compressive strength with different weight percentage additions of glass powder. 


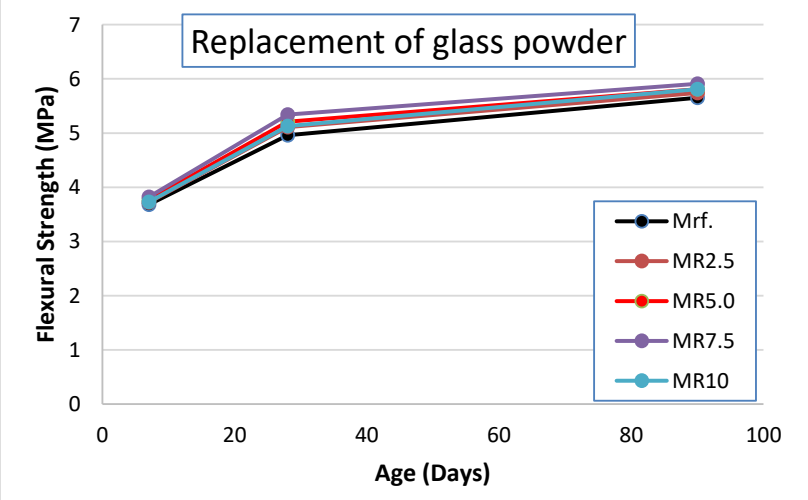

Fig. (5). Development of flexural strength with different weight percentage replacements of glass powder from cement.

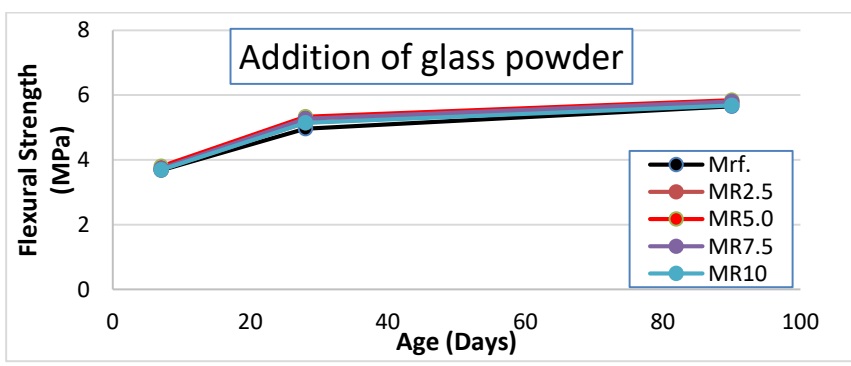

Fig. (6). Development of flexural strength with different weight percentage additions of glass powder.

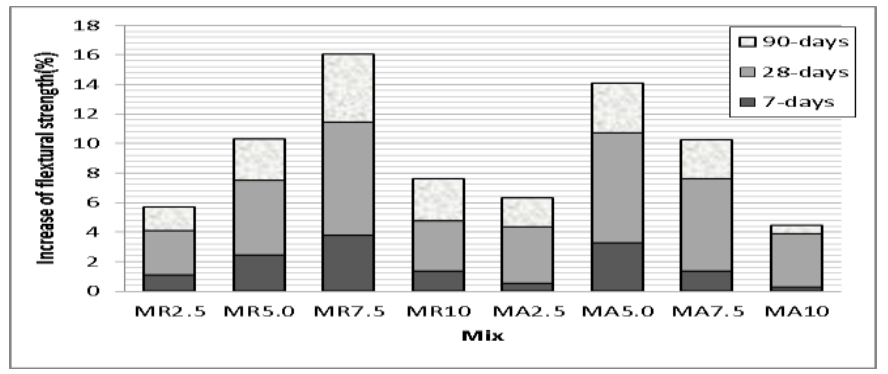

Fig. (7). Cumulative improvement in flexural strength by the replacement and addition of glass powder.

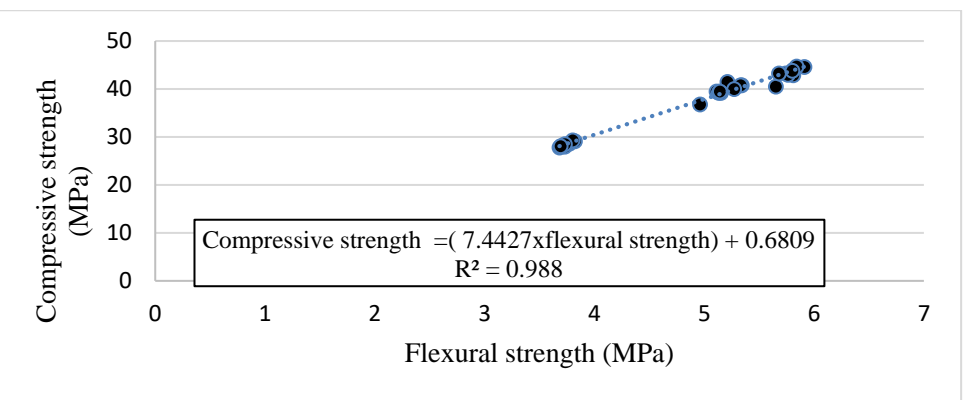

Fig. (8). Relationship of compressive and flexural strengths for all ages. 


\section{CONCLUSION}

[1] Sustainable concrete can be produced using nano glass powder as recycled replacements of cement weight of up to $2.5 \%, 5 \%, 7.5 \%$, and $10 \%$, with good workability and better strength.

[2] The additions of nano glass powder to concrete mix with $2.5 \%, 5 \%, 7.5 \%$, and $10 \%$ as a percentage of cement weight show improvements in compressive and flexural strengths with more demand of water.

[3] The concrete mix with $7.5 \%$ replacement of cement by nano recycled glass powder shows improvements in compressive and flexural strengths of up to $12.77 \%$ and $7.66 \%$, respectively, at 28 days.

[4] The concrete mix containing the $5 \%$ addition by weight of cement of nano recycled glass powder shows improvements in compressive and flexural strengths of up to $11.49 \%$ and $7.46 \%$, respectively, at 28 days.

[5] The mixes with replacement of cement exhibit significant improvements in compressive and flexural strengths with less consumption of cement and environmental pollution.

\section{CONSENT FOR PUBLICATION}

Not applicable.

\section{AVAILABILITY OF DATA AND MATERIALS}

Not applicable.

\section{FUNDING}

None.

\section{CONFLICT OF INTEREST}

The authors declare no conflict of interest, financial or otherwise.

\section{ACKNOWLEDGEMENTS}

Declared none.

\section{REFERENCES}

[1] A.M. Zeyad, A.H. Khan, and B.A. Tayeh, "Durability and strength characteristics of high-strength concrete incorporated with volcanic pumice powder and polypropylene fibers", J. Mater. Res. Technol., vol. 9, no. 1, pp. 806-818, 2020.

[http://dx.doi.org/10.1016/j.jmrt.2019.11.021]

[2] B.A. Tayeh, M.W., A.M. Hasaniyah, Zeyad, M. M Awad, A. Alaskar, A.M. Mohamed, and A.M. Mohamed, "Alyousef. Durability and mechanical properties of seashell partially-replaced cement", J. Build. Eng., vol. 31, 2020.101328

[http://dx.doi.org/10.1016/j.jobe.2020.101328]

[3] S. Shruthi, S. Chandrakala, and G. Narayana, "Partial replacement of cement in concrete using waste glass powder and $\mathrm{m}$-sand as fine aggregate", IJRET, vol. 04, no. 8, pp. 133-138, 2015. [http://dx.doi.org/10.15623/ijret.2015.0408024]

[4] G. Sadiqul Islam, M. Rahman, and N. Kazi, "Waste glass powder as partial replacement of cement for sustainable concrete practice", Int. J. Sustain. Buil. Environ., 2016.

[5] A. Malik, and S. Ashaq, "Experimental evaluation of waste glass powder as a partial replacement of cement concrete", IJSRD, vol. 8, no. 8 , pp. $15-19,2020$.

[6] A. Al-Zubaidi, K. Shabeeb, and A. Ali, "A study of the effect of recycled mix glass on the mechanical properties of green concrete",
Eng. Sci., vol. 26, no. 2, 2018

[7] A.M. Zeyad, B.A. Tayeh, A.M. Saba, and M.A. Johari, "Workability, setting time and strength of high-strength concrete containing high volume of palm oil fuel ash", Open Civ. Eng. J., vol. 12, no. 1, 2018. [http://dx.doi.org/10.2174/1874149501812010035]

[8] D.M. Al Saffar, T.A. Tawfik, and B.A. Tayeh, "Stability of glassy concrete under elevated temperatures", Eur. J. Environ. Civ. Eng., pp. 1-12, 2020.

[http://dx.doi.org/10.1080/19648189.2020.1783368]

[9] M. Ltifi, A. Guefrech, P. Mounanga, and A. Khelidj, "Experimental study of the effect of addition of nano-silica on the behaviour of cement mortars", Procedia Eng., vol. 10, pp. 900-905, 2011. [http://dx.doi.org/10.1016/j.proeng.2011.04.148]

[10] T.A. Tawfik, D.M. AlSaffar, B.A. Tayeh, K.A. Metwally, and I.M ElKattan, "Role of expanded clay aggregate, metakaolin and silica fume on the of modified lightweight concrete properties", Geosys. Engineer., pp. 1-12, 2021.

[11] T. A. Tawfik, K. A. Metwally, S. A. El-Beshlawy, D. M. Al Saffar, B. A. Tayeh, and H. S. Hassan, "Exploitation of the nanowaste ceramic incorporated with nano silica to improve concrete properties", J. King Saud. Uni. Engineer. Sci., 2020.

[http://dx.doi.org/10.1016/j.jksues.2020.06.007]

[12] I.S. Agwa, O.M. Omar, B.A. Tayeh, and B.A. Abdelsalam, "Effects of using rice straw and cotton stalk ashes on the properties of lightweight self-compacting concrete", Constr. Build. Mater., vol. 235, 2020.117541

[http://dx.doi.org/10.1016/j.conbuildmat.2019.117541]

[13] A.M. Zeyad, M.A.M. Johari, B.A. Tayeh, and M.O. Yusuf, "Pozzolanic reactivity of ultrafine palm oil fuel ash waste on strength and durability performances of high strength concrete", J. Clean. Prod., vol. 144, pp. 511-522, 2017.

[http://dx.doi.org/10.1016/j.jclepro.2016.12.121]

[14] M. Nasr, S. Salih, and M. Hassan, "Some Durability Characteristics of Micro Silica and Nano Silica Contained Concrete", J. Babylon University Eng. Sci., vol. 24, no. 4, pp. 980-990, 2016.

[15] A. Hendi, D. Mostofinejad, A. Sedaghatdoost, M. Zohrabi, N. Naeimi, and A. Tavakolinia, "Mix design of the green self-consolidating concrete: Incorporating the waste glass powder", Constr. Build. Mater., vol. 199, pp. 369-384, 2019.

[http://dx.doi.org/10.1016/j.conbuildmat.2018.12.020]

[16] A. Hendi, H. Rahmani, D. Mostofinejad, A. Tavakolinia, and M. Khosravi, "Simultaneous effects of microsilica and nanosilica on selfconsolidating concrete in a sulfuric acid medium", Constr. Build. Mater., vol. 152, pp. 192-205, 2017.

[http://dx.doi.org/10.1016/j.conbuildmat.2017.06.165]

[17] M. Bazhuni, M. Kamali, and A. Ghahremaninezhad, "An investigation into the properties of ternary and binary cement pastes containing glass powder", Front. Struct. Civ. Eng., vol. 13, no. 3, pp. 741-750, 2019. [http://dx.doi.org/10.1007/s11709-018-0511-5]

[18] M. Aly, M.S.J. Hashmi, A.G. Olabi, M. Messeiry, E.F. Abadir, and A.I. Hussain, "Effect of colloidal nano-silica on the mechanical and physical behaviour of waste-glass cement mortar", Mater. Des., vol. 33, pp. 127-135, 2012.

[http://dx.doi.org/10.1016/j.matdes.2011.07.008]

[19] B.A. Tayeh, "Effects of marble, timber, and glass powder as partial replacements for cement", J. Civ. Engineer. Construct., vol. 7, no. 2, pp. 63-71, 2018.

[http://dx.doi.org/10.32732/jcec.2018.7.2.63]

[20] A. Alwared, S. Al-Hubboubi, and R. Rasen, "Effect of waste glass powder as a supplementary cementitious material on the concrete mix properties", Associ. Arab Uni. J. Engineer. Sci., vol. 25, no. 4, pp. 43-54, 2018.

[21] A.I. Jubeh, D.M. Al Saffar, and B.A. Tayeh, "Effect of recycled glass powder on properties of cementitious materials contains styrene butadiene rubber", Arab. J. Geosci., vol. 12, no. 39, 2019. [http://dx.doi.org/10.1007/s12517-018-4212-0]

[22] J. Bernal, E. Reyes, J. Massana, N. León, and E. Sánchez, "Fresh and mechanical behavior of a self-compacting concrete with additions of nano-silica, silica fume and ternary mixtures", Constr. Build. Mater., vol. 160 , pp. 196-210, 2018.

[http://dx.doi.org/10.1016/j.conbuildmat.2017.11.048]

[23] Standard Specification for Portland Cement, ASTM C150/C150M, 2012no. 2010,

[24] Iraqi standard specification for Portland cement, 1984.

[25] Iraqi Standard Specification for Aggregate from Natural Sources for Concrete and Construction, 1984.

[26] Standard Specification for Concrete Aggregates, ASTM C33/C33M- 
13, 2013.

[27] Standard Specification for Coal Fly Ash and Raw or Calcined Natural Pozzolan for Use in Concrete, ASTM C618 - 12a, 2012.

[28] Standard Test Methods for Sampling and Testing Fly Ash or Natural Pozzolans for Use in Portland-Cement Concrete, ASTM C311/C311M - 13, 2013.

[29] Standard Practice for Selecting Proportions for Normal, Heavyweight, and Mass Concrete (ACI 211.1-91), ACI 211-1-91, 2002.

[30] Standard Test Method for Slump of Hydraulic-Cement Concrete, ASTM C143/C143M - 12, 2012.

[31] Standard Practice for Making and Curing Concrete Test Specimens in the Laboratory, ASTM C192/C192M - 14, 2014.

[32] Standard Test Method for Compressive Strength of Cylindrical Concrete Specimens, ASTM C39/C39M - 14a, 2014

[33] Standard Test Method for Flexural Strength of Concrete (Using Simple Beam With Center-Point Loading), ASTM C293/C293M - 10, 2010.

[34] M.H. Hameed, Z.K. Abbas, and A.H.A. Al-Ahmed, "Fresh and hardened properties of nano self-compacting concrete with micro and nano silica", IOP Conf. Series Mater. Sci. Eng., vol. 671, no. 1, 2020.012079

[http://dx.doi.org/10.1088/1757-899X/671/1/012079]
[35] M.M. Yassin, A.S. Mahmoud, and S.M. Hama, "Effectiveness of glass wastes as powder on some hardened properties of concrete", NJES, vol. 22, no. 1, pp. 14-17, 2019.

[http://dx.doi.org/10.29194/NJES.22010014]

[36] Z. Al-Anbori, and A. Al-Obaidi, "Some mechanical properties of concrete by using manufactured blended cement with grinded local rocks", Eng. J. (N.Y.), vol. 22, no. 3, pp. 1-21, 2016.

[37] Z. Abbas, A. Abbood, and H. Awad, "Some properties of mortar and concrete using brick, glass and tile waste as partial replacement of cement", IJSR, vol. 6, no. 5, pp. 1210-1215, 2017.

[38] Z. Abbas, and A. Abbood, "The influence of incorporating recycled brick on concrete properties", IOP Publishing, vol. 1067, no. 1, 2021.012010

[39] B. A. Tayeh, D. M. Al Saffar, A. S. Aadi, and I. Almeshal, "Sulphate resistance of cement mortar contains glass powder", J. King Saud. Uni. Engineer. Sci., 2019.

[http://dx.doi.org/10.1016/j.jksues.2019.07.002]

[40] J.H. Haido, M.A. Zainalabdeen, and B.A. Tayeh, "Experimental and numerical studies on flexural behavior of high strength concrete beams containing waste glass", $A d v$. Concr. Construct., vol. 11, no. 3, p. 239, 2021.

[http://dx.doi.org/10.12989/acc.2021.11.3.239]

\section{(C) 2021 Abbas et al.}

This is an open access article distributed under the terms of the Creative Commons Attribution 4.0 International Public License (CC-BY 4.0), a copy of which is available at: https://creativecommons.org/licenses/by/4.0/legalcode. This license permits unrestricted use, distribution, and reproduction in any medium, provided the original author and source are credited. 